\title{
A ANUÊNCIA DO ESTADO DE MINAS GERAIS NA SUPRESSÃO DE MATA ATLÂNTICA COM A EXCLUSÃO DA RESPONSABILIDADE CIVIL DO DANO AMBIENTAL: A APLICAÇÃO DA BAGATELA NO CAMPO AMBIENTAL
}

\author{
Raphael de Abreu Senna Caronti ${ }^{1}$
}

\section{RESUMO}

Esta pesquisa teve como objetivo refletir sobre a possibilidade de aplicação do instituto da bagatela na responsabilidade civil ambiental, frente às teorias do risco, para tal foi trazido o acórdão n. 1.0000.17.012691-6/002 julgado pelo TJMG como marco teórico. A metodologia adotada é classificada como dedutiva e qualitativa e por meio de bibliografia e jurisprudência. Chegou-se à conclusão que é impossível aplicar a bagatela na responsabilidade civil ambiental, uma vez que os tribunais superiores adotam a teoria do risco integral, cujo intuito é a máxima proteção ao meio ambiente e, por isso, tal decisão é contrária ao meio ambiente.

PALAVRAS-CHAVE: Bagatela; Dano coletivo extrapatrimonial; Mata atlântica; Responsabilidade civil ambiental.

\section{THE CONSENT OF THE STATE OF MINAS GERAIS IN THE SUPPRESSION OF ATLANTIC FOREST WITH THE EXCLUSION OF CIVIL LIABILITY FOR ENVIRONMENTAL DAMAGE: THE APPLICATION OF BAGATELA IN THE ENVIRONMENTAL FIELD}

\begin{abstract}
This research had as objective to reflect on the possibility of application of the trifle institute in the environmental civil responsibility, in face of the risk theories, for this was brought the judgment n. 1.0000.17.012691-6/002 judged by the TJMG as a theoretical framework. The adopted methodology is classified as deductive and qualitative and through bibliography and jurisprudence. It was concluded that it is impossible to apply the trifle in environmental civil liability, since the higher courts adopt the theory of integral risk, whose purpose is the maximum protection of the environment and, therefore, such decision is contrary to the environment.
\end{abstract}

KEYWORDS: Trifle, Collective off-balance-sheet damage; Atlantic forest; Environmental civil liability.

\section{INTRODUÇÃO}

A presente pesquisa avaliará a aplicação da responsabilidade civil ambiental no âmbito do Tribunal do Estado de Minas Gerais, analisando como é tratado casos com dano localizado no bioma da mata atlântica e sua comparação com a jurisprudência do STJ da teoria do risco integral.

\footnotetext{
${ }^{1}$ Mestre em Direito Ambiental pela Escola Superior Dom Helder Câmara, participante do grupo de pesquisa Responsabilidade Civil e Processo Ambiental e Advogado. E-mail: raphaelcaronti@hotmail.com
} 
Para tal, foi selecionado o inteiro teor do acórdão proferido em sede de reexame necessário, do processo 1.0000.17.012691-6/002, pelo Tribunal de Justiça do estado de Minas Gerais (TJMG), que teve como relator o Desembargador Wilson Benevides. O recurso de apelação foi julgado no dia 07/04/2020 com a publicação do acórdão no dia 12/04/2020.

No caso em questão ocorreu degradação de 7,1 hectares do bioma da mata atlântica em uma propriedade privada na cidade de Barbacena no estado de Minas Gerais, cuja primeira instância julgou como parcialmente procedente a ação civil pública movida pelo Ministério Público para determinar apenas a obrigação de fazer de reflorestamento, sem deferir indenização civil.

Em uma prévia leitura da ementa e do inteiro teor do acórdão restou claro que nesse julgamento o tribunal mineiro entendeu pela não aplicação da responsabilidade civil ambiental no caso em comento, julgando pela insignificância do dano ambiental que não foi suficiente para trazer dano coletivo para sociedade. Para efeitos de comparação, será analisado outro acórdão mineiro para cotejar a aplicação da responsabilidade civil ambiental e de decisão do Superior Tribunal de Justiça.

A responsabilidade civil possui substrato na Constituição Federal de 1988, na legislação civil e na doutrina. $\mathrm{O}$ dispositivo constitucional oferece a base da responsabilidade civil e as particularidades são dadas pelo Código Civil e a Lei n. 6.938/81.

Assim, o objetivo da pesquisa é verificar se é correto deixar a pena civil de lado em demandas que envolvam o meio ambiente e a degradação específicas do bioma da mata atlântica, tendo como base a teoria do risco integral. Com esse objetivo, será abordado uma breve contextualização da responsabilidade civil, da responsabilidade civil ambiental para entender os conceitos que serão trabalhados na análise do acórdão.

O primeiro problema a ser verificado será quanto à aplicação da bagatela na teoria da Responsabilidade Civil, ou seja, se é correta sua aplicação ou não. O segundo é a possibilidade da não aplicação da sanção civil e, nesse caso, pergunta-se: as teorias do risco não seriam contraditórias?

Logo, a pesquisa justifica-se pela necessidade de verificar como os tribunais têm decidido sobre a responsabilidade civil em que se aplique a teoria da bagatela aos danos ambientais.

Para tanto, a metodologia adotada pela pesquisa foi pelo método dedutivo, quanto à técnica de pesquisa será feito por meio de bibliografia e jurisprudência e quanto aos fins a pesquisa será qualitativa. 


\title{
A ANUÊNCIA DO ESTADO DE MINAS GERAIS NA SUPRESSÃO DE MATA ATLÂNTICA COM A \\ EXCLUSÃO DA RESPONSABILIDADE CIVIL DO DANO AMBIENTAL: \\ A APLICAÇÃO DA BAGATELA NO CAMPO AMBIENTAL
}

\section{RESPONSABILIDADE CIVIL NO DIREITO BRASILEIRO}

A palavra responsabilidade segundo Paul Ricoeur (1995, p. 35), “define-se pela obrigação de se reparar o dano que se causou por sua falta e, em certos casos, determinados casos determinados pela lei”. Porém, atualmente é melhor o uso da palavra imputar que segundo Paul Ricoeur (1995, p. 38) é “imputar uma ação a alguém é atribuí-la a esse alguém como o seu verdadeiro autor, lança-la por assim dizer à sua conta e torná-lo responsável por ela".

A responsabilidade civil surgiu como forma de vingança, ainda nas civilizações anteriores ao nascimento do Cristo. Primeiramente, ela surgiu como tutela contratual. A tutela extracontratual veio a surgir durante o império romano com a Lex Aquilia, cuja importância é dada por Rezende e Andrade (2019, p. 344), “ampliou a responsabilidade civil para os atos ilícitos, isto é, aqueles praticados por um agente que não possua relação jurídica anterior com o lesado ou que, ainda que possua, não esteja ligada ao dano”. E, neste sentido:

\begin{abstract}
A Responsabilidade Civil tem caráter eminentemente Patrimonial e está prevista no artigo 927 do Código Civil Brasileiro, onde se estabelece os requisitos para se caracterizar a obrigação de indenizar: omissão antijurídica, a culpa ou dolo, o nexo de causalidade e a ocorrência do dano. (POZZETTI, 2017, p. 196)
\end{abstract}

Com relação as penas, elas tinham caráter corporais no início da responsabilidade civil, o que foi mudando com o decorrer do tempo, haja vista percepção que as penas pecuniárias são mais efetivas para reparação e a positivação de direitos humanos que foi evoluindo contra qualquer pena corporal e de escravidão e, nesse sentido aponta Rosenvald:

Na pré-história da responsabilidade civil, pode-se situar a vingança, como a primeira forma de reação contra comportamentos lesivos. Na ausência de um poder central, a vendeta era levada a efeito pela própria vítima ou pelo grupo ao qual pertencia. [...] Apenas em um momento posterior a estas primitivas formas de autotutela, deu-se início à compensação pecuniária [...] (ROSENVALD, 2017, p. 35)

A responsabilidade civil no Império Romano teve caráter punitivo e reparador, servindo de inspiração para os países que utilizam a common law, nesse sentido explica Calandrillo:

Under ancient Roman law, punitive damages were imposed where "the essence of the delict [offense] was not loss but insult, and therefore the money payment must usually have represented not compensation in the ordinary sense, but rather solace 
for injured feelings or affronted dignity. [Hence], the action had the characteristics of a penal action $^{2}$ (CALANDRILLO, 2010, p. 780).

Ademais, as legislações elaboradas durante o império romano serviram de inspiração para as diversas legislações que o seguiram, sendo que o código napoleônico, da França, merece destaque. Isto porque serviu como inspiração para o Código Civil brasileiro em 1916 e para outros países que utilizam o sistema de civil law, sistema adotado pelo Brasil e por países europeus. Nesse sistema ocorre uma segregação entre o direito penal e o civil, e fica a cargo do direito penal a punição e do direito civil a reparação na extensão do dano.

No Brasil, a responsabilidade civil está presente desde o início das codificações, pois nas ordenações do reino ficou previsto no título XXIII que o homem que dormisse com mulher virgem e não se cassasse, seria obrigado a reparar e, nesse sentido, Levy (2009, p. 119) discorreu que eram "previstas penas e indenizações aos sedutores ou raptores nas Ordenações, livro V, título XXIII, quando trata "do que dorme com mulher virgem"”".

Depois das ordenações do reino, surgiu o Código Penal (BRASIL, 1830) e na secção III, estava previsto os crimes de calunia e injúria, com a previsão de penas de restrição de liberdade com a cumulação de multa pecuniária. Assim, nessa legislação houve o acumulo das duas funções, reparatória e punitiva.

A segregação, comentada anteriormente, das matérias, civil e penal, só ocorreu em 1916 com a aprovação do código civil. Ficou disposto que a responsabilidade civil ficaria a cargo do direito civil, com caráter meramente reparatório na extensão dos danos. Já a punição a um ato ilícito ficou a cargo do direito penal, como meio a desestimular condutas. Isso para época foi adequado e funcional, porém, hoje não é mais apropriado e o motivo será explicado mais adiante.

A responsabilidade civil, atualmente, encontra respaldo na Constituição (BRASIL, 1988), cuja previsão genérica é encontrada no rol dos direitos e garantias individuais e coletivos do art. $5^{\circ}$, nos incisos V, no qual explicita: "é assegurado o direito de resposta, proporcional ao agravo, além da indenização por dano material, moral ou à imagem" e no inciso X, "são invioláveis a intimidade, a vida privada, a honra e a imagem das pessoas, assegurado o direito a indenização pelo dano material ou moral decorrente de sua violação”.

\footnotetext{
${ }^{2}$ Sob a lei romana antiga, danos punitivos foram impostos onde "a essência do delito [ofensa] não era perda, mas insulto, e portanto, o pagamento em dinheiro geralmente não deve ter representado compensação no sentido comum, mas sim consolo por sentimentos feridos ou dignidade ofendida. [Portanto] a ação tinha as características de uma ação pena. (tradução nossa)
} 


\section{A ANUÊNCIA DO ESTADO DE MINAS GERAIS NA SUPRESSÃO DE MATA ATLÂNTICA COM A \\ EXCLUSÃO DA RESPONSABILIDADE CIVIL DO DANO AMBIENTAL: \\ A APLICAÇÃO DA BAGATELA NO CAMPO AMBIENTAL}

A previsão específica da responsabilidade civil ficou estabelecido no Código Civil (BRASIL, 2002), cuja previsão encontra-se no art. 927, pois, "Aquele que, por ato ilícito (arts. 186 e 187), causar dano a outrem, fica obrigado a repará-lo".

A divisão de punibilidade realizada no início do século XX, consistente em punição pelo código penal e reparação pelo código civil persiste até hoje. Pois, na jurisprudência ainda impera a pena civil apenas para reparação, sendo um grande problema, uma vez que esse caráter meramente reparatório impossibilita que a responsabilidade civil possa alcançar as outras funções, que é necessário na nossa atual sociedade, pois, a responsabilidade civil é mais eficaz para agir como meio punitivo, devendo atingir um patamar em ser meio de prevenção e precaução aos danos, como base, no direito civil, na sociedade do risco. Neste sentido, sobre a responsabilidade civil do estado assevera Pozzetti:

A responsabilidade civil é a obrigação que se impõe ao Estado de reparar o dano que
o servidor causou, por culpa ou dolo no desempenho de suas funções. A
responsabilidade, para o servidor, nasce do ato culposo e lesivo e se exaure com a
indenização. Esta responsabilidade é independente das demais (da administrativa e
da penal), e se apura na forma do Direito Privado. (POZZETTI, 2017, p. 196)

O direito penal tem que ser deixado como a ultima ratio do direito, devendo as penas privativas de liberdade ou de direitos serem aplicadas somente quando não houver mais medida jurídica para resolução, ou quando a conduta for de alta reprovabilidade social que não permita a convivência no seio populacional.

Tais funções a serem assumidas pela responsabilidade civil são importantes no atual contexto da sociedade, pois, segundo Beck (2010), a sociedade já ultrapassou o status de sociedade industrializada e pós-industrializada, para uma sociedade pautada nos riscos e é preciso criar formas de mitigação desses riscos para manter-se todas as benesses adquiridas pelos seres humanos.

Assim, a responsabilidade civil tem um papel que, segundo Rawls (2000, p. 11), "evitar que se tire alguma vantagem em benefício próprio tomando o que pertence a outrem". E segundo ele, o responsável para evitar que essa vantagem ocorra é de "um sistema público de regras que define cargos e posições em seus direitos e deveres, poderes e imunidades, etc. Essas regras especificam certas formas de ação como permissíveis, outras como proibidas; criam também certas penalidades e defesas”. (RAWLS, 2000, p. 58).

Toda essa matéria reforça que a responsabilidade civil precisa assumir papel de destaque na sociedade como instrumento capaz de ressarcir, punir e prevenir danos, pois do 
contrário permite-se e incentiva-se que condutas lesivas se repitam, o que já foi pensado a muito tempo por Ihering como se pode ver:

\begin{abstract}
Mas o que pode o direito oferecer à pessoa lesada, quando se trata do meu e do teu, senão o objeto da disputa ou o seu valor? Se isso fosse justo, poder-se-ia soltar o ladrão, desde que ele devolvesse o objeto roubado. Mas, objeta-se, ele não só agrediu a vítima, como também as leis do Estado, a ordem jurídica e a lei moral. Será que o devedor, que discorda do preço estabelecido com o vendedor, o locador, que não cumpre o contrato, o mandatário, que trai minha confiança, enganando-me, não fazem o mesmo? Será uma satisfação para mim, se após longa luta com todas essas pessoas, eu nada mais obtiver, senão aquilo que me pertencia desde o início? O perigo que a saída desfavorável do processo lhe trouxe existe para uma perda do que lhe pertence, e para o outro apenas em ter de devolver aquilo que injustamente tomou. A vantagem que a saída possibilita, para um, é o fato de não perder nada, e, para o outro, o de se enriquecer às custas do adversário. Não se estará, assim, exatamente a estimular a mentira mais desavergonhada e dar um prêmio à celebração da deslealdade? (IHERING, 2001, p. 86).
\end{abstract}

Os pressupostos da responsabilidade civil é o trinômio da ação ou omissão, do nexo causal e dano. No início, havia sempre a necessidade em provar a culpa como pressuposto, o que veio a causar alguns desequilíbrios, nesse sentido Rosenvald afirma que: "a exigência de demonstração da prova diabólica da culpa tornava-se um perverso filtro capaz de conter o êxito de demandas indenizatórias". (ROSENVALD, 2017, p. 25).

Para corrigir a teoria surgiu na França, no final do século XIX, a teoria do risco com os idealizadores Saleilles e Josserand ${ }^{3}$, que abriram caminho para o surgimento de uma responsabilidade civil, a objetiva, sem necessidade em se efetuar prova de culpa. (ROSENVALD, 2017).

Diante do exposto, a responsabilidade civil possui duas modalidades: a subjetiva e a objetiva. A modalidade subjetiva consiste na clássica responsabilidade civil, cuja ação ou omissão, nexo causal e dano estão presentes e, há a necessidade de a vítima expor a prova da culpa. Essa modalidade possui aplicação majoritária no código civil.

Já a modalidade objetiva, há a ação ou omissão, o nexo causal e o dano, porém, não há necessidade em se provar a culpa. Para essa desnecessidade de se provar a culpa foi fundada no risco da atividade.

A ação ou omissão, tem sua previsão legal no Código Civil de 2002, no art. 186, pois, “Aquele que, por ação ou omissão voluntária, negligência ou imprudência, violar direito e causar dano a outrem, ainda que exclusivamente moral, comete ato ilícito". Ademais, quem abusa do direito, segundo o Código Civil, art. 187: “Também comete ato ilícito o titular de

\footnotetext{
${ }^{3}$ Saleilles e Josserand foram dois pensadores franceses cujos trabalhos no século XIX deram origem as teorias do risco como forma de trazer uma responsabilidade civil, cuja culpa é o próprio risco da atividade.
} 


\section{A ANUÊNCIA DO ESTADO DE MINAS GERAIS NA SUPRESSÃO DE MATA ATLÂNTICA COM A \\ EXCLUSÃO DA RESPONSABILIDADE CIVIL DO DANO AMBIENTAL: \\ A APLICAÇÃO DA BAGATELA NO CAMPO AMBIENTAL}

um direito que, ao exercê-lo, excede manifestamente os limites impostos pelo seu fim econômico ou social, pela boa-fé ou pelos bons costumes" (BRASIL, 2002).

Nesse sentido, Santiago e Campello (2015, p. 176) discorrem que "gira em torno da ideia de que violar um dever jurídico imposto por um dado ordenamento implica a incidência em ato ilícito, o qual, acarretando dano a outrem, enseja novo dever jurídico, atrelado à reparação de tal prejuízo". Assim, todo ato ou omissão que causar dano a outrem, em regra, será passível de indenização, inclusive quem exceder a um direito.

O nexo causal é um dos elementos na responsabilidade civil, cuja função é realizar a ligação entre a ação ou omissão com o dano; nesse sentido Capelotti (2012, p.91), esclarece que "O nexo causal conecta a consequência danosa à conduta de alguém”. Ou seja, para se falar em reparação é necessário que o dano tenha ocorrido por conta da conduta do agente.

Por fim, o dano é o que Stoco (2013, p. 176) argumenta como "elemento essencial e indispensável à responsabilização do agente, seja essa obrigação originada de ato lícito, nas hipóteses expressam ente previstas, seja de ato ilícito, ou de inadimplemento contratual, independente, ainda, de se tratar de responsabilidade objetiva ou subjetiva”. Assim, o dano é o produto da ação ou da omissão do agente.

Ademais, após a década de 70 o meio ambiente passou a ser motivo de preocupação para o ser humana e motivo de discussão no seio do direito. No mundo jurídico o meio ambiente passou a ter interdisciplinaridade com os ramos do direito e com direito civil não foi diferente, passando a integrar os vários ramos tradicionais e a incluir a preocupação ambiental.

Com a responsabilidade civil não poderia ser diferente, passando a ter uma responsabilidade civil própria, com características próprias que será objeto de estudo do próximo tópico.

\section{RESPOSABILIDADE CIVIL AMBIENTAL}

A necessidade em se tutelar e proteger o meio ambiente surgiu com a constatação de que o homem havia adquirido alto poder de modificação e de destruição do planeta. Fato que foi constatado após a revolução industrial, das grandes guerras mundiais e de desastres que ocorreram. 
Diante dessa percepção, em 1972 grande parte dos governantes mundiais reuniramse, na cidade de Estocolmo, para discutir sobre o meio ambiente e as diretrizes para preservalo. O resultado da conferência foi a elaboração de uma declaração, cujos países assumiram o compromisso em proteger e em positivar as diretrizes para proteção ao meio ambiente. Neste sentido esclarecem Pozzetti e Schettini:

\begin{abstract}
A Declaração de Estocolmo de 1972 foi uma importante fonte inspiradora, pois a proteção do meio ambiente como bem jurídico difuso passou a ser um dos assuntos de relevante interesse nacional, com um capítulo próprio, além de vários outros dispositivos esparsos que buscam o equilíbrio ambiental em todas as atividades humanas. (POZZETTI; SCHETTINI, 2015, p. 299)
\end{abstract}

As repostas mais rápidas à positivação da proteção ao meio ambiente e a constitucionalização como direito fundamental se deram pela Iugoslávia em 1974, na Grécia em 1975, Portugal em 1976 e Espanha em 1978. Embora na Itália e na Suíça já tinham legislações com alguma menção de proteção ambiental ou cultural.

Já a resposta do Brasil com relação à conferência veio no ano de 1981 com a publicação da Lei n. 6.938, a Política Nacional do Meio Ambiente e, só houve a recepção constitucional e o reconhecimento como direito fundamental pela atual Constituição de 1988.

Atualmente diversas constituições no mundo já adotaram o tema ambiental em seu conteúdo e, nesse sentido Sampaio (2016, p. 83-84) demonstra que "Calcula-se [...], hoje, pelo menos, cento e cinquenta Constituições versem sobre a questão ambiental, entre as quais, noventa e duas, no mínimo, fazem-no por meio da afirmação de um direito ao meio ambiente equilibrado". Essa constatação vem para mostrar o sucesso da conferência no quesito das legislações.

A fase pela qual o Brasil vive no direito ambiental, compreendido pela grande parte da doutrina, é antropocêntrica. $\mathrm{O}$ antropocentrismo é aquele em que o homem é considerado, ainda o mais importante, e cujo homem é o centro da proteção e, nesse sentido Sampaio (2016, p. 87) explicita que "Esse direito passou a ser afirmado ou interpretado principalmente em sentido objetivo como dever do Estado, tanto na forma de uma tarefa ou dever estatal, quanto de um princípio ou diretriz de ordem pública ou constitucional, em qualquer caso, sob a reserva de lei”. Mas dizer que o homem é o centro da proteção não significa que se pode fazer o que bem desejar, mas exatamente o contrário, pois proteger o meio ambiente passou a ser questão de sobrevivência para o próprio homem.

Nesse mesmo sentido Costa (2016, p. 72) destaca que "a resolução citada da ONU não pode ser interpretada como uma ruptura com o antropocentrismo, mas sim como uma conscientização da responsabilidade humana perante qualquer forma de vida, sendo ele o 


\section{A ANUÊNCIA DO ESTADO DE MINAS GERAIS NA SUPRESSÃO DE MATA ATLÂNTICA COM A \\ EXCLUSÃO DA RESPONSABILIDADE CIVIL DO DANO AMBIENTAL: \\ A APLICAÇÃO DA BAGATELA NO CAMPO AMBIENTAL}

único animal racional". Isso mostra o tamanho da responsabilidade que o homem possui com o meio ambiente.

Com relação ao conceito de meio ambiente, o mesmo possui diversos conceitos doutrinários e, dentre todos, o mais citado entre os doutrinadores de direito é o conceito dado por José Afonso da Silva e segundo ele:

O meio ambiente é, assim, a interação do conjunto de elementos naturais, artificiais e culturais que propiciem o desenvolvimento equilibrado da vida em todas as suas formas. A integração busca assumir uma concepção unitária do ambiente, compreensiva dos recursos naturais. (SILVA, 2009, p. 20)

O objeto que se busca tutelar no direito ambiental é o bem ambiental e a doutrina em sua maioria entende um bem ambiental não é somente os bens naturais, mas também engloba os bens artificiais, cuja criação é realizada pelo homem e, nesse meio ambiente artificial, está incluso o meio ambiente do trabalho, os monumentos e a cultura e, acerca desse bem ambiental:

\footnotetext{
observa que o artigo 225 da CF de 1988 compreende o bem ambiental "como um todo composto de partes imprescindíveis e, ao mesmo tempo, autônomas, que devem ter protegidas suas características essenciais. Assim, a partir da CF de 1988 tem-se um maior compartilhamento de instrumentos protetivos aos bens que dão suporte ao meio ambiente ecologicamente equilibrado. Pois ele é "instituto realizador da dignidade da pessoa humana e um veículo que ao mesmo tempo conduz e reflete a qualidade de vida. (SOARES, 2007, p. 15)
}

Quanto ao caráter desse bem ambiental, Costa (2016, p. 62) demonstra que "o direito à integridade ao meio ambiente como um direito difuso, o qual não possibilita um estreitamento de seus beneficiários, que compreendem todas as pessoas sem distinção e não há uma relação jurídica básica". Por conta desse caráter, a constituição no seu art. 225 assegura a todos um meio ambiente sadio e qualidade de vida, como direto fundamental.

$\mathrm{Na}$ base do direito ambiental estão os princípios constitucionais ambientais, nesse sentido Costa (2016, p. 64) postula que os princípios "são necessários à efetivação da garantia constitucional dos direitos fundamentais". Para tal, segundo Costa (2016, p. 65) "o Estado é o instrumento de promoção do bem-estar social garantido pela democracia social". Assim, é demonstrado a importância de princípios sólidos e da atuação do Estado para garantir sua implementação.

As diretrizes de desenvolvimento é outro ponto que merece destaque, pois a partir da ECO-92 que se definiu a necessidade, o conceito e as bases para um desenvolvimento sustentável que discorre Costa (2016, p. 60) como "manter e preservar o meio ambiente, como todos devem fazer hoje, para a próxima geração, e assim sucessivamente". Os recursos 
naturais são finitos e cada vez mais escasso e 'por isso, espera-se que ocorra o que Costa (2016, p. 81) discorre, "espera-se que as gerações futuras descubram soluções viáveis para cumprir a obrigação de proteção ao meio ambiente". Esse é o grande desafio da atual geração de pesquisadores.

O Direito Ambiental possui vários princípios que lhe dão embasamento, todavia o artigo não se ocupará de todos eles, pois não é o foco do estudo. Assim, Costa (2016 p. 160) os enumeram como sendo: "o direito ambiental, tendo como base os princípios de prevenção, precaução, sustentabilidade, poluidor-pagador, informação, cooperação, participação e solidariedade vem assegurar a existência humana e não humana, ou seja, a vida em todas as formas".

Entre esses princípios, conforme pensamento de Dworkin (1999) não há hierarquia entre eles e em caso de concorrência entre eles a resolução se dá pelo o que Dworkin (2001, p. 133) discorreu que "Quando princípios concorrem entre si [...], aquele a quem incumbe resolver o conflito deve tomar em consideração o peso relativo de ambos".

Diante dessa importância para o homem é recomendável que a responsabilidade civil atue de forma preventiva para sua proteção agindo antes do dano, nesse sentido:

O objetivo do Direito Ambiental é estabelecer regras cogentes, de maneira a prevenir danos futuros. Neste sentido, o direito ambiental atua no campo educativo, preventivo e não no âmbito reparador. As regras são postas no sentido de que as ações sejam tomadas antes que o dano se consolide. Como a crise ambiental assola o planeta como um todo, gerando diversas catástrofes, o direito ambiental se consolida através dos Princípios que lhe são próprios, no sentido de se invocá-los diante da ameaça de danos à saúde pública e ao meio ambiente. (POZZETTI; MONTEVERDE, 2007, p. 200)

Logo, levando em consideração a importância do meio ambiente, a responsabilidade civil precisa ter proteção especial em comparação com a responsabilidade civil tradicional operada pelo direito civil, pois os danos ambientais são totalmente diferentes dos danos do direito civil, uma vez que o meio ambiente demora muito tempo para formar aquele ecossistema e ao caráter difuso. Dessa forma, esses danos ambientais possuem o seguinte conceito:

Dano ambiental significa, em uma primeira acepção, uma alteração indesejável ao conjunto de elementos chamados meio ambiente, como, por exemplo, a poluição atmosférica; seria, assim, a lesão ao direito fundamental que todos têm de gozar e aproveitar do meio ambiente apropriado. Contudo, em sua segunda conceituação, dano ambiental engloba os efeitos que esta modificação gera na saúde das pessoas e em seus interesses. (LEITE; AYALA, 2015, p.104)

A proteção aos danos ambientais obteve uma vitória recente em um julgado perante o Supremo Tribunal Federal (STF), pois foi declarado que a pretensão da responsabilidade civil 


\section{A ANUÊNCIA DO ESTADO DE MINAS GERAIS NA SUPRESSÃO DE MATA ATLÂNTICA COM A \\ EXCLUSÃO DA RESPONSABILIDADE CIVIL DO DANO AMBIENTAL: \\ A APLICAÇÃO DA BAGATELA NO CAMPO AMBIENTAL}

por danos ambientais é imprescritível, apesar de já haver antes da confirmação julgados dos tribunais e da doutrina já defender essa imprescritibilidade. Dessa forma, segue ementa do referido julgado do STF:

Decisão: O Tribunal, por maioria, apreciando o tema 999 da repercussão geral, extinguiu o processo, com julgamento de mérito, em relação ao Espólio de Orleir Messias Cameli e a Marmud Cameli Ltda, com base no art. 487, III, b, do Código de Processo Civil de 2015, ficando prejudicado o recurso extraordinário, nos termos do voto do Relator, vencidos os Ministros Gilmar Mendes, Marco Aurélio e Dias Toffoli (Presidente), que davam provimento ao recurso. O Ministro Roberto Barroso acompanhou o Relator com ressalvas. Foi fixada a seguinte tese: "É imprescritível a pretensão de reparação civil de dano ambiental”. Falou, pela assistente, o Dr. Antonio Rodrigo Machado de Sousa. Não participou deste julgamento, por motivo de licença médica no início da sessão, o Ministro Celso de Mello. (BRASIL, 2020)

Por isso, em matéria ambiental, a responsabilidade civil é objetiva, fundada na teoria do risco integral. Sendo a responsabilidade civil uma das três modalidades de punição pelo dano ambiental positivados pela Constituição (1988, art. 225, §3º), assim, “As condutas e atividades consideradas lesivas ao meio ambiente sujeitarão os infratores, pessoas físicas ou jurídicas, a sanções penais e administrativas, independentemente da obrigação de reparar os danos causados".

Portanto, na responsabilidade civil ambiental não é necessário demonstrar a culpa do agente causador de degradação, bastando demonstrar a conduta e o nexo causal, que dependendo do caso poderá ser flexibilizado também.

Essa demonstração da culpa sempre foi um vilão da responsabilidade civil e, nesse sentido Bedran e Mayer (2013, p. 48), "sempre houve uma enorme dificuldade em demonstrar a culpa do agente causador do dano [...]". Ademais, o $\S 1^{\circ}$ do art. 14 da Lei n. 6.938/81 trouxe de forma clara a opção pela aplicação da responsabilidade civil objetiva no direito ambiental.

A aplicação dessa modalidade é a efetivação, segundo Ribeiro e Vasconcellos Júnior (2020, p. 149) decorre da aplicação do "princípio do poluidor-pagador é direcionado para se evitar a privatização do lucro em detrimento da socialização do prejuízo ambiental [...]". Além que conforme trabalhado alhures, ser medida de resposta frente a responsabilidade de risco.

O Brasil resolveu, jurisprudencialmente, adotar a teoria do risco integral, pois não há lei que positive a teoria do risco integral, nem sobre sua aplicação. Apesar disso, a jurisprudência trouxe essa aplicação ao Brasil e entende hermeneuticamente que o $\S 1^{\circ}$ do art. 14 da Lei n. 6.938/81 é onde está positivado acerca da aplicação do risco integral no Brasil, conforme pode ser verificado nesse acórdão do STJ: 
6. Responsabilidade objetiva e solidária de todos os agentes que obtiveram proveito da atividade que resultou no dano ambiental não com fundamento no Código de Defesa do Consumidor, mas pela aplicação da teoria do risco integral ao poluidor/pagador prevista pela legislação ambiental (art. 14, $\S 1^{\circ}$, da Lei $\mathrm{n}^{\mathrm{o}}$ 6.938/81), combinado com o art. 942 do Código Civil. (BRASIL, 2015).

Pois bem, o referido artigo trata apenas da aplicabilidade da responsabilidade civil objetiva, não podendo confundir os dois conceitos e nem aplicar de forma indiscriminada interpretações hermenêuticas.

O referido tribunal, que é responsável por uniformizar a interpretação de lei federal, entender que deve aplicar tal teoria, que aplique, pois, a mesma é mais protetiva ao meio ambiente. Ademais é importante que o Brasil proteja mais o meio ambiente natural pela importância da sua biodiversidade.

Assim, a teoria do risco integral se baseia em um risco extremo ao meio ambiente que, como consequência, discorre que qualquer ameaça ao bem ambiental aplica-se a responsabilidade civil objetiva, sem necessidade de provar culpa, porém, com o nexo causal flexibilizado em casos que assim necessitem. Nesse sentido Steigleder (2011, p. 172) enfatiza que "a grande problemática envolvendo o nexo de causalidade na área ambiental é que o dano ambiental pode ser resultado de várias causas, concorrentes, simultâneas ou sucessivas, dificilmente tendo uma única e linear fonte". Por isso que o nexo causal poderá ser mitigado no direito ambiental.

Essa teoria não aceita a aplicação das excludentes do nexo causal, pois segundo Bedran e Mayer (2013, p. 53), "pode levar a situações de não responsabilização, [...] que passa a invocar culpa de terceiros ou da vítima, caso fortuito ou força maior para exonerar-se do dever de indenizar, em prejuízo ao princípio basilar do Direito Ambiental, que é o da precaução". Tudo isso para efetivar a proteção ambiental com suas especificidades.

A responsabilidade civil ambiental é um dos três mecanismos para proteção ambiental e é o que mais possui potencialidade para combater de forma eficaz a degradação ambiental. Isso, porque a esfera penal deve ser tratada como ultima ratio e as penas que o ordenamento pátrio prevê são baixas e quanto a responsabilidade administrativa ela ainda mescla as ordenações civis e penais e isso pode trazer insegurança jurídica.

Dessa forma, a responsabilidade civil ambiental precisa agir como protagonista e se separar das amarras do civil law, e trazer um pouco da cultura do punitive damages, claro que com moderação e utilizando o bom senso, pois isso vai trazer que a função preventiva da responsabilidade civil seja cumprida. 


\title{
A ANUÊNCIA DO ESTADO DE MINAS GERAIS NA SUPRESSÃO DE MATA ATLÂNTICA COM A \\ EXCLUSÃO DA RESPONSABILIDADE CIVIL DO DANO AMBIENTAL: \\ A APLICAÇÃO DA BAGATELA NO CAMPO AMBIENTAL
}

Ademais, a falta de punição e de fixação de indenização gera o comportamento de impunidade e que vale a pena ter esse comportamento, estimulando comportamentos indesejáveis para o meio ambiente e nesse sentido:

\begin{abstract}
Afinal, é muito cômodo para o potencial causador de um ato antijurídico ter o conhecimento de que o descumprimento do dever de conduta - seja por um ato ilícito como por um inadimplemento - ficará limitado ao montante dos prejuízos causados e nada mais. $\mathrm{O}$ agente percebe que a retribuição do sistema será inferior ao proveito auferido pelo ilícito. (ROSENVALD, 2017, p. 47)
\end{abstract}

Por fim, além da imposição da obrigação de fazer ou não fazer, é necessário, também, a fixação da pena civil e com um valor para reparar os danos causados e que o mesmo tempo irá desestimular essas condutas, pois deve ser levado em consideração que os danos ambientais em alguns casos não comportam a reparação a status quo ante. Por isso, os julgados não podem aplicar apenas a obrigação de fazer ou de não fazer, deixando de lado a pena civil sob o argumento da bagatela do dano ambiental.

\section{RESPONSABILIDADE AMBIENTAL POR CORTE DE VEGETAÇÃO NATIVA: ACÓRDÃO DE APELAÇÃO 1.0000.17.012691-6/002 DO TJMG}

Este caso trata da Ação Civil Pública interposta pelo Ministério Público do estado de Minas Gerais tendo como base a degradação do meio ambiente de 7,1 hectares do bioma de mata atlântica, em uma propriedade privada na cidade de Barbacena no Estado de Minas Gerais, conforme ementa abaixo:

EMENTA: REEXAME NECESSÁRIO CONHECIDO DE OFÍCIO, NOS LIMITES DA IMPROCEDÊNCIA - APELAÇÃO CÍVEL - AÇÃO CIVIL PÚBLICA POR RESPONSABILIDADE AMBIENTAL - CORTE DE VEGETAÇÃO NATIVA, INTEGRANTE DO BIOMA MATA ATLÂNTICA - IMPOSIÇÃO DE OBRIGAÇÕES DE FAZER - DANO MORAL COLETIVO - DESCABIMENTO SENTENÇA CONFIRMADA. Utilizando-se da ação civil pública para resguardar o meio ambiente, aplica-se o microssistema da tutela coletiva, o qual abarca a Lei federal $n^{\circ} 4.717 / 65$, que regula a Ação Popular, diploma que impõe o reexame da sentença em relação ao pedido julgado improcedente. Para a caracterização do dano moral coletivo, faz-se necessário que o ato transgressor viole valores fundamentais coletivos e seja de tamanha significância que promova alterações significativas na ordem extrapatrimonial coletiva. Segundo o órgão ministerial, houve agressão direta a uma área de 7,1hectares, degradando o já parco Bioma da Mata Atlântica, protegido pela Lei $\mathrm{n}^{\circ} 11.128 / 06$. Em que pese à responsabilidade civil ambiental, compulsando o caderno processual, não é possível inferir que o corte de vegetação nativa, sem a autorização dos órgãos ambientais competentes, apesar de ter degradado o meio ambiente, no caso, o bioma da Mata Atlântica, em uma extensão de 7,1ha, tenha afetado diretamente uma coletividade de pessoas. Inexistindo essa prova, inviável a condenação do requerido. (MINAS GERAIS, 2020). 
A sentença determinou a obrigação de fazer para cercar o local da degradação, apresentar projeto para recuperação da área realizada por profissional qualificado, executar as medidas necessárias para recomposição da área. A obrigação de fazer só será dada como cumprida com a avaliação dos técnicos e, por fim, o pagamento de multa se não tiver a possibilidade de recomposição da área.

Não foi considerado pelo magistrado, que julgou em primeira instância, e nem pelos desembargadores que julgaram o recurso de apelação que o dano ambiental fosse o suficiente para passar da esfera do dano material, ou seja, da mera reparação, como observado nesse trecho do referido julgado do TJMG (Minas Gerais, 2019), "Consoante constou da v. sentença, embora reconhecido o dano ambiental material, não há prova do dano moral coletivo, ou seja, não restou provado que o fato em discussão repercutiu na esfera social". Para tal foi utilizado o argumento:

\begin{abstract}
Com efeito, para a caracterização do dano moral coletivo, faz-se necessário que o ato transgressor viole valores fundamentais coletivos e seja de tamanha significância que promova alterações significativas na ordem extrapatrimonial coletiva. Em uma concepção mais ampla, o dano moral ambiental resulta configurado quando houver decréscimo para a saúde, tranquilidade e qualidade de vida em geral das pessoas, de forma indeterminada, como decorrência da agressão a bens ambientais, ou quando se verificar a perda da oportunidade de fruição pelas gerações atuais e futuras de bens de valor histórico-cultural ou paisagístico. (MINAS GERAIS, 2019)
\end{abstract}

Pois bem, o bioma referido possui proteção constitucional que segundo Moura (2006, p. 8), "apresenta-se como um conjunto bastante diversificado de ecossistemas florestais, os quais têm como fator comum mais relevante a umidade, condicionada principalmente pela influência de massas de ar provenientes do Oceano Atlântico", com uma área que segundo Moura (2006, p. 8) cobre "17 estados brasileiros, nas regiões Nordeste, Sudeste, Centro-Oeste e Sul".

Esse bioma possui suma importância para o planeta, pois Moura (2006, p. 11) discorre que ele "abriga um elevado número de espécies. Embora as florestas tropicais ocupem apenas $7 \%$ da superfície do planeta, elas abrigam aproximadamente a metade das espécies existentes".

Além do mais, segundo Moura (2006, p. 12-13) ele “desempenha um papel importante no clima do planeta, por participar ativamente do ciclo do carbono [...] A remoção da floresta em áreas tropicais provoca o rápido empobrecimento do solo. [...] provoca a erosão dos solos e o assoreamento dos mananciais aquíferos". Demonstrado a importância do bioma e da importância em se proteger. 


\title{
A ANUÊNCIA DO ESTADO DE MINAS GERAIS NA SUPRESSÃO DE MATA ATLÂNTICA COM A \\ EXCLUSÃO DA RESPONSABILIDADE CIVIL DO DANO AMBIENTAL: \\ A APLICAÇÃO DA BAGATELA NO CAMPO AMBIENTAL
}

Tal bioma também é escasso como afirma Moura (2006, p. 10): "Hoje restam cerca de 100 mil km, o que corresponde somente a 7,6\% da área original". E devido a essa escassez o bioma foi incluído como Hot Spot do planeta, conforme conceito abaixo:

\begin{abstract}
Os Hot Spots são zonas de perigo, ou seja, áreas de elevada biodiversidade, sujeitas a um altíssimo risco de desaparecer. Para ser considerado um Hot Spot uma área deve possuir pelo menos 1.500 espécies de plantas endêmicas e já ter perdido mais de três quartos da sua vegetação original. No Brasil, dois biomas são incluídos entre os 25 Hot Spots do planeta: a Mata Atlântica e o Cerrado. Os Hot Spots são zonas de perigo, ou seja, áreas de elevada biodiversidade, sujeitas a um altíssimo risco de desaparecer. Para ser considerado um Hot Spot uma área deve possuir pelo menos 1.500 espécies de plantas endêmicas e já ter perdido mais de três quartos da sua vegetação original. No Brasil, dois biomas são incluídos entre os 25 Hot Spots do planeta: a Mata Atlântica e o Cerrado. (MOURA, 2006, p. 11)
\end{abstract}

Devido a importância do bioma, qualquer degradação é ofensa ao direito coletivo. E o tamanho da degradação não pode ser motivo para deixar de aplicar a responsabilidade civil, pois, somando-se os danos causado, ao final tem-se uma grande devastação e, conforme trabalhado alhures, é um bioma que possui vital importância e sua degradação afeta a coletividade de modo geral. Portanto, na medida que há a limitação humana a esse bioma, previne-se a degradação de flora e fauna e não se pode tolerar a aplicação de institutos de bagatela na degradação de tal bioma, mesmo que se impute a obrigação de fazer, conforme será trabalhado a seguir.

\section{DA APLICAÇÃO DA BAGATELA NO DIREITO AMBIENTAL E O JULGADO DO TJMG}

$\mathrm{O}$ instituto da bagatela foi pensado para o direito penal e quer dizer que em certos crimes devidos a baixa ofensividade não deve ser imputado e, nesse sentido Dias (2009, p. 37) discorreu que "Nessa perspectiva do STF vem adotando o princípio da insignificância e bagatela quando a ofensividade da conduta do agente for mínima e a ação não revele nenhuma periculosidade social".

Porém, não pode ser aceito a aplicação do instituto da bagatela no direito ambiental e, principalmente, sobre a responsabilidade civil ambiental, pois o meio ambiente, conforme disposto acima, é um patrimônio difuso por natureza e que no campo da responsabilidade civil possui uma proteção anormal, na medida que aplica-se a modalidade objetiva e a teoria do risco integral, visando justamente a máxima proteção ao meio ambiente. Assim, acerca da 
impossibilidade de aplicação da bagatela no direito ambiental o Tribunal de Justiça de Minas Gerais chegou ao seguinte entendimento:

1. A incolumidade do meio ambiente não pode ser comprometida por interesses individuais, assim como a responsabilidade civil objetiva na seara ambiental, informada pelos princípios do poluidor-pagador e da reparação in integrum, não pode ser elidida pela aplicação do princípio da bagatela. (MINAS GERAIS, 2014)

Somado a isso, Rosenvald (2017) defende que a responsabilidade civil deve assumir papel além da mera reparação advinda do direito francês, para assumir, também, um papel punitivo e preventivo aos danos. E, se torna mais importante, a possibilidade em punir como forma de evitar condutas, de preveni-las e como forma da população saber que se degradar irá sofrer uma pena civil, uma vez que o status quo nem sempre é possível.

A não punição ou a punição ineficaz é capaz de trazer a sensação de que cometer tais atos valem a pena e que cometer tais condutas compensam, para ilustrar isso segue o entendimento que foi extraído do acórdão decidido pelo Tribunal de Minas Gerais:

3. A recusa ou aplicação parcial dos princípios do poluidor-pagador e da reparação in integrum arrisca projetar, moralmente, a nociva impressão de que o ilícito ambiental compensa. Diante disso, a resposta judicial no caso de dano ambiental há de ser enérgica, sob pena de a impunidade do ofensor servir de inspiração social. (Voto do Revisor) (MINAS GERAIS, 2014)

Acerca da aplicação da multa civil como meio de evitar comportamentos, o STJ enfrentou o tema em julgamento em 2017 que se tornou informativo n. 643 em 2019 em matéria ambiental, e votou pela aplicação da multa civil e pela possibilidade de fomentar condutas indesejadas pela não aplicação, conforme observado na ementa do acordão:

PROCESSO REsp 1.574.350-SC, Rel. Min. Herman Benjamin, por unanimidade, julgado em 03/10/2017, DJe 06/03/2019 RAMO DO DIREITO DIREITO ADMINISTRATIVO, DIREITO AMBIENTAL, DIREITO CIVIL TEMA Direito ao trânsito seguro. Tráfego de veículos de carga com excesso de peso. Proteção da saúde e segurança das pessoas e consumidores, assim como do patrimônio público e privado. Danos materiais e morais coletivos. Ocorrência. Aplicação de multa civil (astreinte). Cumulatividade com multa administrativa. Possibilidade. [...] No caso analisado verificou-se que a lucratividade com o peso excessivo compensa e supera eventual pagamento de multa administrativa, o que comprova a incapacidade da sanção para reprimir e desencorajar a conduta legalmente vedada. Saliente-se que a existência de penalidade ou outra medida administrativa in abstracto (para o futuro) ou in concreto (já infligida), como resposta a determinada conduta ilegal, não exclui a possibilidade e a necessidade de providência judicial, nela contida a de índole cautelar ou inibitória, com o intuito de proteger os mesmos direitos e deveres garantidos, em tese, pelo poder de polícia da Administração, seja com cumprimento forçado de obrigação de fazer ou de não fazer, seja com determinação de restaurar e indenizar eventuais danos materiais e morais causados ao indivíduo, à coletividade, às gerações futuras e a bens estatais. Registre-se que a multa civil (astreinte), frequentemente utilizada como reforço de autoridade da e na prestação jurisdicional, não se confunde com multa administrativa [...]. Por seu turno, indisputáveis os danos materiais, assim como o nexo de causalidade. $O$ transporte com excesso de carga nos caminhões causa dano material e extrapatrimonial in re ipsa ao patrimônio público 


\section{A ANUÊNCIA DO ESTADO DE MINAS GERAIS NA SUPRESSÃO DE MATA ATLÂNTICA COM A \\ EXCLUSÃO DA RESPONSABILIDADE CIVIL DO DANO AMBIENTAL: \\ A APLICAÇÃO DA BAGATELA NO CAMPO AMBIENTAL}

(consubstanciado em deterioração de rodovia federal), ao meio ambiente (traduzido em maior poluição do ar e gastos prematuros com novos materiais e serviços para a reconstrução do pavimento), à saúde e segurança das pessoas (aumento do risco de acidentes, com feridos e mortos) e à ordem econômica. Portanto, inafastável a relação entre a conduta do agente e o dano patrimonial imputado [...]. Por fim, confirma-se a existência do dano moral coletivo em razão de ofensa a direitos coletivos ou difusos de caráter extrapatrimonial - consumidor, ambiental, ordem urbanística, entre outros -, podendo-se afirmar que o caso em comento é de dano moral in re ipsa, ou seja, deriva do fato por si só. (BRASIL, 2019, Grifos nossos)

Assim, o próprio Superior Tribunal de Justiça abre o caminho para aplicabilidade aos danos ambientais da cumulação de condenação civil da obrigação de fazer com os danos extrapatrimoniais com intuito de inibir condutas e evitar que se torne vantajoso comete-las. Isso segue na linha de pensamento dos doutrinadores civilistas tal como Rosenvald em dar a responsabilidade civil um papel tríplice de reparador, punitivo e preventivo, sendo ainda mais necessário quando se tratar do bem ambiental e cuja importância já é reconhecida, pois aplicamos a teoria do risco integral que traz a máxima proteção ambiental. (ROSENVALD, 2017).

Portanto, em danos ambientais, por menores que sejam, deve haver, por parte da responsabilidade civil, a imputação da pena de obrigação de fazer para restaurar o bioma, a obrigação de não fazer para não mais desmatar e a aplicação da pena civil pecuniária para os fins de cumprir com a tríplice função defendida na pesquisa e que se agrava quando envolve o meio ambiente.

\section{CONSIDERAÇÕES FINAIS}

A problemática que motivou essa pesquisa foi a de verificar se os tribunais estão aplicando a bagatela com relação a responsabilidade civil ambiental, pois é aplicado pelo Superior Tribunal de Justiça a teoria do risco integral para buscar a máxima proteção ambiental e deixar de aplicar as penas civis é totalmente contraditório a essa teoria do risco.

Os objetivos foram cumpridos à medida em que se analisou o acordão e verificou que o Tribunal de Justiça de Minas Gerais aplica a bagatela, sendo totalmente contrário a teoria do risco integral aplicado pelo Superior Tribunal de Justiça e, mais grave quando se verifica a importância do bioma degradado.

A pesquisa obteve como resultados a breve passagem pelo histórico da responsabilidade civil com seu início nas sociedades anteriores ao nascimento do Cristo como forma de vingança, com o nascimento da responsabilidade civil codificada, cuja introdução 
foi dado pelo Direito Romano, a criação da teoria do risco na França no século XIX em pleno Iluminismo e Revolução Francesa, a chegada da responsabilidade civil no Brasil, cuja origem vêm do início das codificações brasileiras, a adoção da teoria do civil law pelo Brasil, cujas ideias foram inspiradas no Direito Napoleônico.

Dessa forma, se chegou ao estágio atual da responsabilidade civil com as modalidades subjetiva e objetiva e com a criação de uma responsabilidade civil especial para tutelar o meio ambiente, cujo objetivo, no Brasil, é se tutelar melhor o meio ambiente. Para tal, se aplica ao meio ambiente a modalidade objetiva, cuja culpa é dispensada, com a aplicação da teoria do risco integral que possibilita, em alguns casos, da flexibilização do nexo causal.

Portanto, o papel da responsabilidade civil atual é a reparação dos danos causados e da necessidade em se imputar outros papeis para responsabilidade civil, o de prevenção e punição.

Apesar disso, o Tribunal de Justiça de Minas Gerais, no acordão estudado, cujo desmatamento de 7,1 hectares do bioma da Mata Atlântica em propriedade privada na cidade de Barbacena, resolveu pela aplicação, na área cível, de somente a obrigação de fazer frente ao dano ambiental, sem que condenasse a pena civil conforme requerido pelo Ministério Público e indo contrário ao entendimento do Superior Tribunal de Justiça de se buscar uma máxima proteção ao meio ambiente.

Portanto, deixar de aplicar a pena civil em casos de danos ambientais é aplicar o instituto da bagatela ao direito ambiental e incentivar a prática de tais condutas, uma vez que se torna barato desmatar.

Dessa forma, não se pode permitir a aplicação do instituto da bagatela no direito ambiental. É necessário, assim, a aplicação da multa civil nos danos ambientais, ainda mais no bioma da Mata Atlântica, pois no Brasil o Superior Tribunal de Justiça vem caminhando na máxima proteção ao meio ambiente, da cumulação de penas e da possibilidade de penas punitivas como forma de prevenção aos danos ambientais. Assim, os Tribunais Estaduais têm que se moldar a esse pensamento.

\section{REFERÊNCIAS}

BEDRAN, Karina Marcos; MAYER, Elizabeth. A Responsabilidade Civil por Danos Ambientais no Direito Brasileiro e Comparado: Teoria do Risco Criado Versus Teoria do Risco Integral. Veredas do Direito: Direito Ambiental e Desenvolvimento Sustentável, Belo Horizonte, v. 10, n. 19, p. 45, set. 2013. Disponível em: 


\section{A ANUÊNCIA DO ESTADO DE MINAS GERAIS NA SUPRESSÃO DE MATA ATLÂNTICA COM A \\ EXCLUSÃO DA RESPONSABILIDADE CIVIL DO DANO AMBIENTAL: \\ A APLICAÇÃO DA BAGATELA NO CAMPO AMBIENTAL}

http://revista.domhelder.edu.br/index.php/veredas/article/view/271/339. Acesso em: 30 abr. 2020.

BECK, Ulrich. Sociedade de risco: rumo a uma outra modernidade. 1. ed. São Paulo: 34, 2010. 384p.

BRASIL. Código Criminal (1830). Código Criminal do Império do Brazil. Disponível em: http://www.planalto.gov.br/ccivil_03/leis/lim/lim-16-12-1830.htm. Acesso em: 01 jul. 2020.

BRASIL. Constituição (1988). Constituição da República Federativa do Brasil. Brasília: Senado Federal, Centro Gráfico, 1988.

BRASIL. Código Civil (2002). Lei n. 10.406, de 10 de janeiro de 2002. Código Civil. Disponível em: <http://www.planalto.gov.br/ccivil_03/leis/2002/110406.htm>. Acesso em: 07 mai. 2020.

BRASIL. Superior Tribunal de Justiça. REsp. 1.363.107, Rel. Ministro Paulo de Tarso Sanseverino. Diário de Justiça Eletrônico, Brasília, 17 de dezembro de 2015.

BRASIL. Superior Tribunal de Justiça. REsp. 1.574.350, Rel. Ministro Herman Benjamin. Diário de Justiça Eletrônico, Brasília, 06 de março de 2019. Disponível em: https://ww2.stj.jus.br/docs_internet/informativos/ramosdedireito/informativo_ramos_2019.pdf . Acesso em: 23 abr. 2020.

BRASIL. Supremo Tribunal Federal. RExt. 654.833, Rel. Ministro Alexandre de Morais. Diário de Justiça Eletrônico, 20 de abril de 2020. Disponível em: http://stf.jus.br/portal/jurisprudenciaRepercussao/verAndamentoProcesso.asp?incidente $=4130$ 104\&numeroProcesso=654833\&classeProcesso=RE\&numeroTema=999\#. Acesso em: 30 abr. 2020.

CALANDRILLO, Steve P. Penalizing Punitive Damages: Why the Supreme Court Needs a Lesson in Law and Economics. George Washington Law Review, Washington DC, v. $78 \mathrm{n}$. 4, p. 774-821. 2010. Disponível em: https://digitalcommons.law.uw.edu/faculty-articles/132. Acesso em: 24 abr. 2020.

CAPELOTTI, João Paulo. O nexo causal na responsabilidade civil: entre a certeza e a probabilidade. 2012. 164 f. Dissertação (Mestrado) - pós-graduação em direito da Universidade Federal do Paraná, Paraná, 2012.

COSTA, Beatriz Souza. Meio ambiente como direito à vida: Brasil, Portugal e Espanha. 3. ed. Rio de Janeiro: Lumen Juris, 2016.

DIAS, Sandro. O delito da bagatela e o auto de prisão em flagrante. Revista Científica do ITPAC, Araguaína, v. 2, n. 3, p. 36-39, jul. 2009. Disponível em: https://assets.unitpac.com.br/arquivos/Revista/23/5.pdf. Acesso em: 01 jul. 2020.

DWORKIN, Ronald. O império dos direitos. Trad. Jefferson Luiz Camargo. São Paulo: Martins Fontes, 1999. 
DWORKIN, Ronald. É o direito um sistema de regras? Estudos Jurídicos, São Leopoldo, v.34, n.92, p. 119-158, set./dez. 2001.

IHERING, Rudolf Von. A luta pelo direito. trad. José Cretella Jr. e Agnes Cretella, São Paulo: Revista dos Tribunais, 2001.

LEITE, José Rubens Morato; AYALA, Patryck de Araújo. Dano ambiental: do individual ao coletivo extrapatrimonial: teoria e prática. São Paulo: Revista dos Tribunais, 2015.

LEVY, Maria Stella Ferreira. A escolha do cônjuge. Revista brasileira de estudo de população, São Paulo, v. 26, n. 1, p. 117-133, jan./jun. 2009. Disponível em: http://www.scielo.br/scielo.php?script=sci_arttext\&pid=S0102-

30982009000100009\&lng=en\&nrm=iso. Acesso em: 21 abr. 2020.

MINAS GERAIS, Tribunal de Justiça. Recurso de Apelação 6166096-79.2009.8.13.0702. Relator: Teresa Cristina da Cunha Peixoto. Belo Horizonte. 03 de fevereiro de 2014. Disponível https://www4.tjmg.jus.br/juridico/sf/relatorioAcordao?numeroVerificador=107020961660960 02201491462. Acesso em: 22 abr. 2020.

MINAS GERAIS, Tribunal de Justiça. Recurso de Apelação 1.0000.17.012691-6/002. Relator: Wilson Benevides. Belo Horizonte. 07 de abril de 2020. Disponível em: https://www4.tjmg.jus.br/juridico/sf/proc_resultado2.jsp?tipoPesquisa2 $=1 \&$ txtProcesso $=1000$ $0170126916002 \&$ nomePessoa $=\&$ tipoPessoa $=X \&$ naturezaProcesso $=0 \&$ situacaoParte $=X \&$ cod igoOAB2 $=\&$ tipoOAB $=\mathrm{N} \&$ ufOAB $=\mathrm{MG} \&$ numero $=20 \&$ select $=1 \&$ listaProcessos $=1000017012$ $6916002 \&$ tipoConsulta $=1 \&$ natureza $=0 \&$ ativoBaixado $=X \&$ comrCodigo $=0024$. Acesso em 20 abr. 2020.

MOURA, Flavia de Barros Prado Moura (org.). A Mata Atlântica em Alagoas. Maceió: EDUFAL, 2006. [e-book]

POZZETTI, Valmir César; SCHETTINI, Mariana Cruz. a responsabilidade civil do empregador pelos danos no meio ambiente do trabalho. Veredas do Direito, Belo Horizonte, v. $12, \quad$ n.24, p.287-318, jul./dez. 2015. Disponível em: http://revista.domhelder.edu.br/index.php/veredas/article/viewFile/489/463. Acesso em: 15 mai. 2020.

POZZETTI, Valmir Cesar; MONTEVERDE, Jorge Fernando Sampaio. Gerenciamento ambiental e descarte de lixo hospitalar. Veredas do Direito, Belo Horizonte, v. 14, n. 28, jan./abr. 2017.

POZZETTI, Valmir César. Responsabilidades da administração pública na liberação de alimentos transgênicos no Brasil. Cadernos de Dereito Actual N $^{\circ} 7$ Extraordinário (2017). Disponível em: http://www.cadernosdedereitoactual.es/ojs/index.php/cadernos/article/view/223/139. Acesso em 15 mai. 2020. 


\section{A ANUÊNCIA DO ESTADO DE MINAS GERAIS NA SUPRESSÃO DE MATA ATLÂNTICA COM A \\ EXCLUSÃO DA RESPONSABILIDADE CIVIL DO DANO AMBIENTAL: \\ A APLICAÇÃO DA BAGATELA NO CAMPO AMBIENTAL}

RAWLS, John. Uma teoria da justiça. Trad. Almiro Pisetta e Lenita M. R. Esteves. São Paulo: Martins Fontes, 2000.

REZENDE, Elcio Nacur; ANDRADE, Renato Campos. Responsabilidade Civil empresária diante da omissão de "compliance" ambiental - uma análise à luz do "contrato social" de Jean-Jacques Rousseau. Revista Eletrônica Direito e Política, Programa de PósGraduação Stricto Sensu em Ciência Jurídica da UNIVALI. Itajaí, v.14, n.2, $2^{\circ}$ quadrimestre de 2019. Disponível em: www.univali.br/direitoepolitica. Acesso em: 02 abr. 2020.

RIBEIRO, José Claudio Junqueira; VASCONCELLOS JÚNIOR, Jayro Boy de. Avaliação de impacto ambiental: origem, normatização e a (in)efetividade no âmbito dos processos de licenciamento ambiental brasileiro. Revista Internacional de Direito Ambiental, Caxias do Sul, a. IX, n. 25, p. 133-154, jan./abr. 2020. [e-book]

RICOEUR, Paul. O justo ou a essência da justiça. Lisboa: Instituto Piaget, 1995.

ROSENVALD, Nelson. As funções da responsabilidade civil: a reparação e a pena civil. 3. ed. São Paulo: Saraiva, 2017.

SAMPAIO, José Adércio Leite. Os ciclos do constitucionalismo ecológico. Revista Jurídica da FA7. Fortaleza, v. 13, n. 2, p. 83-101, jul./dez. 2016. Disponível em: https://periodicos.uni7.edu.br/index.php/revistajuridica/article/view/65. Acesso em: 31 mar. 2020 .

SANTIAGO, Mariana Ribeiro; CAMPELLO, Livia Gaigher Bósio. A Responsabilidade Civil por Atividade de Risco e o Paradigma da Solidariedade Social. Veredas do Direito: Direito Ambiental e Desenvolvimento Sustentável, Belo Horizonte, v. 12, n. 23, p. 25, out. 2015. Disponível em: http://revista.domhelder.edu.br/index.php/veredas/article/view/451/444. Acesso em: 05 abr. 2020.

SILVA, José Afonso da. Direito ambiental constitucional. 7. ed. São Paulo: Malheiros, 2009.

SOARES, Inês Virgínia Prado Soares. Proteção Jurídica do Patrimônio Arqueológico no Brasil: fundamentos para efetividade da tutela em face de obras e atividades impactantes. Erechim: Habilis, 2007.

STEIGLEDER, Annelise Monteiro. Responsabilidade Civil Ambiental: as Dimensões do Dano Ambiental no Direito Brasileiro. 2. ed. Porto Alegre: Livraria do Advogado Editora, 2011, 278 p.

STOCO, Rui. Tratado de responsabilidade civil, tomo I. 9. ed. São Paulo: Revista dos Tribunais, 2013. 